\title{
Priority directions of innovative development of Russian fuel and energy complex on global investment market
}

\author{
Natalia Sidorova ${ }^{1}$, Irina Repina ${ }^{1, *}$, Victoria Timchenko ${ }^{1}$ \\ ${ }^{1}$ Far Eastern Federal University (FEFU), Engineering school, 690018 Russky Island, Russia.
}

\begin{abstract}
Energy production is the most important system-forming infrastructure in the Russian Far East. The Asia-Pacific Region retains the position of the most attractive region in terms of investment into new projects, but the investment prospects of the region in terms of development of the fuel and energy sector on the global investment market consists of ten factors. 27 state programs specifically target the Far East, meanwhile small and medium businesses will also be given means for development.
\end{abstract}

Keywords: infrastructure, energy production, investment, targets, investment prospects, factors, rise for development, Ministry of the Russian Federation for the Development of the Far East priority development area.

The geopolitical risks of relations with Western countries are forcing Russia to seek new markets for its capital, goods and services, as well as new markets for selling its own products. Paying attention to Asian countries (China, India, Singapore, South Korea, Hong Kong, Japan, etc.) as sources of investment to the Russian economy the government focuses on the underdeveloped infrastructure of the country.

Energy production is the most important systemforming infrastructure in the Russian Far East. Attraction of private investments in the Russian economy is possible only on condition of solving problems of the infrastructure of the Far East, which then will attract investments in industrial production in the territorial points of growth.

The Asia-Pacific region (the APR) maintains the position of the most attractive region for investment in new projects: in 2014, the region is ahead of Europe and North America taken together concerning the share of announced foreign direct investment in new projects. When direct foreign investments in new projects were structured over a period of 2012-2014, the statistics were as follows: the APR - 33\%, Europe - 37\%, North America and other countries $-30 \%$.

The investment prospects of the region for the development of the fuel and energy complex on the global investment market is made up of ten factors, their importance depends on the type of the investor:

1. Access to natural resources (the level of extraction of natural resources, reserves of natural resources);

2. Stability (macroeconomic certainty, stability in a country's politics, legal stability)

3. Corruption
4. Tax advantage

5. Access to home and foreign markets

6. Infrastructure (automobile transport, air transportation, railway transportation)

7. Labour costs

8. Quality of human resourses

9. Suppliers

10. Innovations

In the near future, the APR can become the world's largest investor in new projects: over the past five years, the average dynamics of the region is more favorable than in other regions of the world.

Comparison of the parameters of the investment prospects of the Far Eastern Federal District and the countries of the Asia-Pacific Region.

Economic conditions in the countries of the Asia-Pacific region:

1. Tax on profits (percent of profits / 2016): South Korea - 18.2; China - 11.1; Singapore - 2; USA 27.4; Canada - 3.9; Japan - 28.9; Russia - 0 .

2. Energy prices (US cents per 1 kilowatt of energy / 2016): South Korea - 9.2; China - 11; Singapore no data available; USA - 9.4; Canada - 7.2; Japan 28; Russia - 6.3.

3. Connecting infrastructure to power supply source (days / 2016): South Korea - 18; China - 143; Singapore - 31; USA - 90; Canada - 137; Japan 98; Russia - 160 .

At present, the government views the Far East as a Russian super-region. 27 state programs are specifically targeted at the Far East, which is to become a strong outpost of Russia in the Asia-Pacific region. Such a prioritization decision has been made for the first time.

\footnotetext{
Corresponding author: repina_ira@mail.ru
} 
So, one of the priorities of making the region a strong outpost is to attract additional investments to it. This became possible due to adopting a legislative proposal aimed at equalizing energy tariffs in the Far Eastern Federal District with the all-Russian level. Energy tariffs for industrial consumers will be reduced since July 1, 2017. The basic level, to which the tariffs will be reduced, is 3.19 rubles per $1 \mathrm{kWh}$. In this case in Primorsky Krai, the reduction is $21 \%$.

In accordance with the law, tariffs in the Far East will be reduced to the average Russian level due to a premium to the price of capacity in the I and II price zones. The manager of the raised funds will be PJSC RusHydro, which can receive RUB 29.5 billion for these purposes in 2017-2019.

The cheapening of electricity became possible after the Russian President Vladimir Putin approved the amendments to the federal law "On Energy". The corresponding law of December 28, 2016 No. 508-FZ entered into force on January 1, 2017.

According to the data of the Ministry of Regional Development, on average for the Far East tariffs will decrease by $30 \%$. The biggest drop will occur in Chukotka $-65 \%$, in Yakutia - 50\%, on Sakhalin - 46\%, in the Magadan region - 34\%. In Primorsky Krai, the tariff will decrease by $21 \%$, in Kamchatka - by $20 \%$, in the Jewish Autonomous Region by $17 \%$, in the Amur Region and Khabarovsk Territory by $5 \%$.

PJSC RusHydro is supposed to transfer funds intended to reduce tariffs in the Far East to the regions' budgets, where they will go to energy sales companies. The drafts of normative and legal acts prepared by the RF Ministry of Energy say: "The funds received from the introduction of the bonus for the territories of the Far Eastern Federal District are used to provide specialpurpose non-repayable contributions to the budgets of the constituent entities of the Russian Federation that represent a part of the Far Eastern Federal District".

RusHydro will act as a premiums gatherer: the money will first be credited to the company's special account, and then within five days it will be transferred to the budgets of the subjects of the Far Eastern Federal District. This financial scheme will allow to reduce tariffs to the all-Russian level.

The development of fuel-energy complex is influenced by many factors. First of all, the scale and pace of productive forces development, especially energy production. At the same time, fuel and energy complex significantly affects the formation and development of all sectors of the national economy and its main components - industry, agriculture, transport and communications, construction and public utilities [14].

The factors shaping it and determining rational structure of fuel and energy complex, affecting its efficiency is divided into classes:

1. Economic - inflation, subsidies, prices of means of production;
2. Organizational - the size of a company, its legal form, system management organization (attraction of innovative solutions), organization of accounting, development of export and import substitution industries in the areas with the most favorable conditions, the formation of special economic zones and technoparks as regional centers for domestic and world science achievements introduction, accelerating economic and social progress.

3. Natural - climatic conditions, territorial disposition of land and water areas for mining and production of mineral resources for the energy sectorReduction in electricity price became possible after amending Federal law №508 “About energetics”, which came into effect January 1, 2017.

4. Social - the living conditions of the population consuming the products of fuel and energy complex, working conditions of workers employed in the fuel and energy complex, etc.

Profit is the difference between revenues and production and sales costs [21], therefore, it is important to affect primarily the cost for the manufacturer. He can reduce costs while constant volume of production and sales, increase production at the same cost or increase the volume of production and sales at a faster pace in comparison with rising costs [1].

Factors influencing profit:

1. The cost of production. It depends on the standard costs and consumption rates of labor, material and technical resources, funds, compliance with the technological requirements for the production of fuel resources and the provision with heat and light. The cost per unit of production impacts on unit costs in the unit cost of production [22].

2. The cost of transportation and direct sales of commercial products which is an essential element in the full commercial cost. Their share depends on the type of products, distribution channels, intermediaries and other averaging from 5 to $15 \%$. This kind of cost is affected by the development of market infrastructure, road network, tariffs for services (transport , information, insurance, communications and so on);

Selling price is a variable opportunistic category, which is influenced by supply and demand, distribution channels, government policy on prices, quality characteristics of product. Prices of fuel and energy complex products are formed under the influence of many factors. Inflation expectations and the interests of producers influence strongly

The degree of company production resources utilization depends on all these factors. Economic efficiency of rationality is measured by profit and its relation to the full cost of products sold and aggregate funds 
According to the Ministry of Economic Development of the Russian Federation, the average tariff reduction throughout Far East will reach 30\%. The greatest reduction will be on Chukchi Peninsula - 65\%, in Yakutia - 50\%, on Sakhalin - 46\%, in Magadan Region $-34 \%$. In Primorsky Kray it will be $21 \%$, on Kamchatka $-20 \%$, in Jewish Autonomous Region - 17\%, in Amur Region and Khabarovsk Territory $-5 \%$.

RusHydro is suspected to transfer money for tariff reduction in Far East to regional budgets, then the money will proceed to energy sales companies.

"The funds raised by the application of premium in the Far Eastern Federal District, are using for nonrepayable goal-oriented contributions to the budgets of constituent entities of the Russian Federation, which are members of the Far Eastern Federal District", - stated in the draft legal acts prepared by the Ministry of Energy.

Energy supply companies that guarantee regional supplies will receive money in the form of subsidies directly from the budgets.

"Far Eastern Energy Company" (DEK) - a subsidiary of PJSC RusHydro - now acts as the main guaranteed supply company in the II non-price zone that includes the Far East. DEK also has the status of a single buyer of the II non-price zone. The main shareholders of DEK are PJSC RAO ES Vostok (100\% subsidiary RusHydro) with a $51.03 \%$ stake and the Donalink Ltd in Cyprus (controlled by Joint-Stock Company SUEK) with a 34\% stake.

The Resolution of the Government of the Russian Federation defines the features of the concept "the advanced development of the Far East". This is to show core indicators in all areas above the national average level. Today, the basis for the development of the region is the law on priority development areas (PDA). The Government of the Russian Federation has decided to create PDAs for seventy years. The information on the current benefits and preferences for residents of PDA is presented in Table 1.

All benefits and preferences are based on the proposal of the authorized federal body (Ministry of the Russian Federation for the Development of the Far East). This proposal stipulates:

- a list of types of economic activities performed under a special legal regime for economic activities according to Federal Law;

- the minimum volume of capital investments of residents in the relevant types of economic activity in the priority development areas;

- regulations on the use or non-use of the customs procedure of the free customs zone established by the customs legislation of the Customs Union;

- defining the borders of the priority development areas;

- minimum requirements for the level of technologies, production methods, and equipment used by residents of the PDA realizing various types of economic activities.
Ministry of the Russian Federation for the Development of the Far East executes:

- issuance of construction permits, permits to place objects of construction into use, reconstruction of infrastructure facilities permits, with the exception of the objects and facilities specified in paragraph 5.1 of Part 1 of Article 6 of the Town Planning Code of the Russian Federation, and with the exception of highways of federal importance;

Table 1. Current benefits and preferences for residents of PDA.

\begin{tabular}{|c|c|c|c|c|}
\hline $\begin{array}{l}\text { Type } \\
\text { of tax }\end{array}$ & $\begin{array}{l}\text { Tax } \\
\text { rate } \\
\text { with } \\
\text { out } \\
\text { bene } \\
\text { fits } \\
\text { and } \\
\text { prefe } \\
\text { rence } \\
\text { s } \\
\end{array}$ & $\begin{array}{l}\text { Tax rate } \\
\text { with regard } \\
\text { to benefits } \\
\text { and } \\
\text { preferences }\end{array}$ & $\begin{array}{l}\text { Duratio } \\
\mathrm{n} \text { of } \\
\text { benefit } \\
\mathrm{s} \text { and } \\
\text { prefere } \\
\text { nces }\end{array}$ & $\begin{array}{c}\text { The basis of the } \\
\text { benefits and } \\
\text { preferences }\end{array}$ \\
\hline $\begin{array}{l}\text { Income } \\
\text { tax } \\
\text { federal } \\
\text { regiona } \\
1\end{array}$ & $20 \%$ & $\begin{array}{l}0 \% \text { over } \\
\text { first } 5 \text { years } \\
\text { since the } \\
\text { date of } \\
\text { making } \\
\text { profit, then } \\
12 \%(2 \% \text { - } \\
\text { federal, } \\
10 \% \text { - } \\
\text { regional })\end{array}$ & $\begin{array}{l}10 \\
\text { years }\end{array}$ & $\begin{array}{l}\text { The second part of } \\
\text { the Tax Code of the } \\
\text { RF }\end{array}$ \\
\hline $\begin{array}{l}\text { Corpor } \\
\text { ate } \\
\text { propert } \\
\text { y tax }\end{array}$ & $2,2 \%$ & $\begin{array}{l}0,5 \% \text { over } \\
\text { first } 5 \\
\text { years, } 1,1 \% \\
\text { - over } \\
\text { second } 5 \\
\text { years since } \\
\text { the date of } \\
\text { resident's } \\
\text { activity }\end{array}$ & $\begin{array}{l}10 \\
\text { years }\end{array}$ & $\begin{array}{l}\text { The second part of } \\
\text { the Tax Code of the } \\
\text { RF }\end{array}$ \\
\hline $\begin{array}{l}\text { Deduct } \\
\text { ions for } \\
\text { social } \\
\text { needs }\end{array}$ & $30 \%$ & $\begin{array}{l}7,6 \% \\
- \text { Pension } \\
\text { Fund of the } \\
\text { RF 6\%; } \\
\text { - Social } \\
\text { Insurance } \\
\text { Fund of the } \\
\text { RF 1,5\%; } \\
\text { - The RF } \\
\text { Compulsor } \\
\text { y Medical } \\
\text { Insurance } \\
\text { Fund } 0,1 \%\end{array}$ & $\begin{array}{l}10 \\
\text { years }\end{array}$ & $\begin{array}{l}\text { Federal Law No. } \\
212-F Z \text { of July 24, } \\
2009 \text { "On Insurance } \\
\text { Contributions to the } \\
\text { Pension Fund of the } \\
\text { Russian Federation, } \\
\text { the Social Insurance } \\
\text { Fund of the Russian } \\
\text { Federation, the } \\
\text { Federal Compulsory } \\
\text { Medical Insurance } \\
\text { Fund" }\end{array}$ \\
\hline
\end{tabular}

- coordination of the territorial planning scheme of the subject of the Russian Federation in which the PDA is created;

- harmonization of documents on planning the PDA for the location of capital construction projects of regional importance within the boundaries of the municipality in which the PDA is located, the implementation of state construction supervision in cases provided by the Town Planning Code of the Russian Federation;

- approval of the draft plan of PDA for the purpose of its integrated development; 
- approval of the procedure for maintaining a register of residents;

- control over the compliance of the agreement by the resident of the PDA;

- control over the activities of the management company and its subsidiaries;

- harmonization of documents on territorial planning of municipal objects within the boundaries of the PDA and documents on use and development of land;

- provision of land under federal ownership located in the PDA;

- taking decisions on reservation of land and compulsory alienation of land plots (withdrawal of land plots) for state needs for locating infrastructure facilities in the PDA; also creation of a state servitude to land plots for the purpose of locating infrastructure facilities of the PDA;

- consideration of complaints against refusals to make an Agreement on the Implementation of Activities. Minimum growth of producer prices for heat in the pair was awarded in 2011 -by $3.8 \%$. In 2013 compared with the previous year, prices for heat in the pair increased by $12 \%$, heat in hot water by $11.2 \%$, which is close to the price level of 2009 [24, 25].

- In Russian Federation tariff increases in production, transmission and distribution of electricity amounted to $6.2 \%$, heat $-11.5 \%$ in 2013 . In the production of fuel and energy minerals prices decreased by 5

It should be specially noted that within the frames of this process small and medium businesses would also be given rise to development, thus providing employment for local residents.

\section{References}

1. FEC and the economy of Russian regions. Far Eastern Federal District (Publishing house ENERGY, Moscow, 2007)

2. A. Bolgov, S. Markov, Energy Market: Portrait of the region, 06(67) (2009). http://www.e-m.ru/

3. UNCTAD

4. Innovation and entrepreneurship. http://www.innovbusiness.ru/content/document_r_7 C5F2FBB-3749-41CF-9706-ED2784B8E677.html

5. I.B. Svetlova, Fuel and energy complex of the Far East of Russia (Development and prospects: Report of the director of the ANO "CSI TEK DV", Vladivostok, 2013)

6. Information about the special economic zones of the PRC. Portal Foreign economic information of the Ministry of Economic Development of the Russian
Federation. http://www.ved.39gov.ru/export countries/cn/about_cn/laws_ved_cn/special_area_cn /

7. Energy strategy of Russia for the period until 2030. $\mathrm{http} / / /$ minenergo.gov.ru/aboutminen/energostrategy/

8. Ministry of Energy of the Russian Federation. http://minenergo.gov.ru/

9. Far Eastern Federal District. https://en.wikipedia.org/wiki/Дальневосточный_фе деральный_округ

10. Strategy of social and economic development of the Far East and the Baikal region for the period until 2025. http: //www.dfo.gov.ru/

11. Federal Service of State Statistics. www.gks.ru

12. zrpress.ru

13. The Law of the Russian Federation of December 28 , 2016 No. 508-FZ entered into force on 2017. http://minenergo.gov.ru

14. On the Priority Development Areas in the Russian Federation: Federal Law No. 473-FZ of 2014.

15. Center for Energy Efficiency. http://cenef.ru

16. I.A. Bashmakov, Development of integrated longterm energy saving and energy efficiency programs: methodology and practice (Moscow, 2013)

17. World energy model - methodology and assumptions. World Energy Outlook 2007, International Energy Agency, Paris. www.worldenergyoutlook.org/docs/weo2007/WEM _Methodology_07.pdf

18. Innovation strategy. Types of innovation strategies. http: // www.rae.ru/monographs/112-3771

19. M. Filipini, L.K. Hunt, Measurement of energy efficiency based on economic fundamentals (Energy Economy, 2015)

20. dv.kapital.ru

21. N.G. Sidorova, Vestnik of the Plekhanov Russian University of Economics, 10(64), 110-113 (2013)

22. The state program of the Russian Federation "Socioeconomic development of the Far East and the Baikal Region" approved by the decree of the government of Russian Federation of 2013.

23. World Energy Perspective. Cost of Energy Technologies. Www.worldenergy.org/wpcontent/uploads/2013/09/WEC_J1143

CostofTECHNOLOGIES_021013_WEB_Final.pdf;

24. Excerpts from Dmitry Medvedev are opening remarks. government.ru/en/news/15480;

25. To divide the world economy into five. www.gazeta.ru/business/2013/12/25/5819085.shtml 